\title{
Educational Justice Praxis and Cultural Competence
}

\section{Dilek Kayaalp}

Assistant Professor, Teaching, Learning and Curriculum, University of North Florida

\begin{abstract}
In this study I investigate how culture, cultural norms, and teachers' habitus (habits to dispositions) affect the implementation of educational justice praxis (theory and practice) as a response to alleviate the structural inequities faced by ethnic/racial minority students. This study also suggests culturally appropriate educational tools that pre-service teachers can use in their cross-cultural classrooms. Using qualitative methods, I conducted interviews with 12 teachers and teacher educators who work in public schools, nonprofit organizations, and universities in Florida, United States. My findings expose how dominant cultural norms (whiteness), teachers' habitus (white fragility), and structural problems (racism) help to marginalize ethno-racial minority students and suppress their educational rights. The findings suggest that combating racism, questioning dominant norms/values, and accepting distinct cultural identities should be the components of educational justice praxis.
\end{abstract}

Keywords: Cultural Norms; Teachers' Habitus; Educational Justice; Whiteness; Racism; United States

\section{Introduction}

Can theoretical frameworks and pedagogical models help to alleviate the structural inequities faced by ethnic/racial minority students? While exploring students' self-identifications and their educational interests are appropriate approaches to educational justice, finding the "best" educational praxis (i.e., theory and practice in educational equity; Gramsci, 1971) presents a challenge. However, Gorski's (2016) argument on culture, cultural competency, and multicultural education provided a useful place to start meeting this challenge.

Gorski criticizes a congratulatory perspective in multicultural education which celebrates food, music and cultural festivals, but ignores the issues of inequality, power, and privilege. Gorski argues (2016, p. 1),

a focus on culture, the meaning of which remains intensely contested, stunts the possibility of real progress toward educational justice. [...] I argue for a new commitment to centering equity rather than culture in conversations and practices related to educational justice.

According to this view, culture should not be the only frame of reference for conversations about social justice education. Rather, educational justice should be discussed along with issues of power imbalances and inequalities.

Although I generally accept Gorski's interpretation, I argue that equity, equality, and educational rights cannot be separated from cultural matters; dominant cultural values (e.g. whiteness) and norms (e.g. white fragility, i.e., inability to tolerate racial stress, entitlement to racial comfort, and withdrawal from any encounter with non-white groups) impact the cultural identities and rights, including language rights, of ethno-racial minority students. Accepting the cultural identities of students complements the search for educational justice praxis and the fight against racism.

Consequently, in this study I develop a theoretical framework to explore the interplay of cultural competence, equity, and the various aspects of culture in education. This study also provides new information about culturally sensitive pedagogies for educators. It indicates the impacts of structural inequalities (racism) and teachers' habitus (whiteness and white fragility) on the educational rights and educational attainments of students.

\section{Theoretical Considerations}

Recognizing the cultural backgrounds of students and confronting systemic racism in educational settings are central to educational justice praxis. Therefore, interrogating ethnocentrism, Eurocentrism, and whiteness should be key in exploring 
the dominant cultural norms that marginalize ethno-racial minority students and hinder their educational rights (Gay, 2010). As DiAngelo (2011) argues, whiteness might be better understood within the context of racism.

Racism, as a form of oppression, legitimizes inequality, exclusion, and subordination in society and educational settings (Anthias \& Yuval-Davis, 1992; Hall, 2000). Racism has a conjunctural character and cannot be separated from the structures of society (Hall cited in Lewis 2000), and therefore must not be homogenized.

For Hall (2000, p. 222), racism "claims to ground the social and cultural differences which legitimate racialized exclusion in genetic and biological differences." Hall argues that,

Biological racism privileges markers like skin color, but those signifiers have always also been used, by discursive extension, to connote social and cultural differences. 'Blackness' has functioned as a sign that people of African descent are closer to Nature, and therefore more likely to be lazy, indolent, over-sexualized, with low-self-control. Correspondingly, those who are stigmatized on ethnic grounds, because they are 'culturally different' and therefore inferior, are often also characterized as physically different in significant ways, underpinned by sexual stereotypes. The biological referent is therefore never absent from discourses of ethnicity (p. 223).

Since racism works discursively with an articulation of cultural and biological differences, Hall talks of "racism's two logics." That is, racism works both through cultural differences (such as cultural practices like language and religion) and biological differences (such as skin colour). Here, Hall connects biological racism with cultural racism and thus avoids depicting cultural racism as "less" racist than biological racism and therefore more tolerable.

According to cultural racism, ethno-racial minorities are not "inferior" because of their racial/ethnic background, but because they do things "differently" (Cohen, 1999). That is, their religious practices, names, clothes, customs, and foods are deemed inferior. Their accents are incomprehensible, or their dialects are sub-standard (Kayaalp, 2014). Refusal to acknowledge the existence of individual and cultural differences of students, including their self-identification, is itself a form of racism. Cultural identities in their various aspects (such as language) are significant reference points for severely marginalized students whose stories and histories have been systematically and historically omitted from the curriculum and textbooks.

Therefore, culturally responsive teaching and educational justice must respect students' racial/ethnic and linguistic identities (Gay, 2010), and acknowledge the powerful system of shared values and norms in the cultural context that shapes group identities and creates power imbalances and oppression in social and educational settings (Sensoy and DiAngelo, 2017). These cultural categories or categories of identification are always socially and contextually (through time and space) constructed.

Students' social locations and their educational experiences, including their hopes and fears, are determined by the asymmetrical power dynamics and dominant cultural norms that surround them. By focusing on culture and the dominant cultural norms, one can reveal the forms of injustice, oppression, domination, and power imbalance generated by the existing cultural framework. Whiteness as a dominant cultural norm and practice, for example, exalts white people's status and marginalizes non-white people's position and their cultural identities.

Culturally responsive teaching should thus stress the impacts of whiteness (as a social construct) and also the role of white fragility (as habitus--habits, life style, taste, dispositions) that demonizes ordinary people and encourages segregation in educational settings. According to DiAngelo (2011), whites perceive any social and racial encounter with people of color as a challenge to their identities and to the system which protects their privileges and dominance. DiAngelo argues,

White people in North America live in a social environment that protects and in- sulates them from race-based stress. This insulated environment of racial protec- tion builds white expectations for racial comfort while at the same time lowering the ability to tolerate racial stress, leading to what I refer to as White Fragility. White Fragility is a state in which even a minimum amount of racial stress be- comes intolerable, triggering a range of defensive moves. These moves include the outward display of emotions such as anger, fear, and guilt, and behaviors such as argumentation, silence, and leaving the stressinducing situation. These behaviors, in turn, function to reinstate white racial equilibrium (p. 1).

In countries such as the United States and Canada, whiteness protects its dominance through certain cultural practices, beliefs, and values. White fragility and the protection of white privilege through manipulation make whiteness a permanent dominant cultural norm. Explicit and implicit, de facto segregation create comfortable sites for whites that compartmentalize lifestyles, limit social and physical interactions, and constrain all manner of relationships between white and non-white 
people. Whiteness remains protected, and white fragility is perpetuated through those segregated spaces and life styles. White fragility thus must become part of culturally responsive teaching.

\section{Methods}

In this qualitative inquiry, I collected data through in-depth interviews. The interviews were conducted with 12 teachers and teacher educators who work in public schools, nonprofit organizations, and universities in Florida, USA, to investigate teacher educators' interpretation of culture, cultural identities, and equity. The interviews further addressed the research questions (see below) and explored the elements of cultural competence and educational rights in teacher education programs.

Participants dedicated to the project approximately 1 hour during the 12-month period from May 2018 to May 2019. The interviews were conducted at a location specified by the participants, such as the participant's office. With participant consent, these discussions were audio taped and transcribed for anonymity. In addition to interviews, I conducted a literature review focusing on the issues of systemic racism and cultural competence. I also analyzed publicly available secondary data (i.e., internship data from teacher education programs).

The research objectives were clustered around two themes: i) teacher's identity, white culture and white fragility; and ii) culturally appropriate pedagogical models.

Recruitment to the study was done through personal contacts. I met most of my potential participants in both formal meetings and informal get-togethers (holiday parties) at the college where I work. Meetings and random encounters in the college helped me build trust relationships with my colleagues. I contacted prospective participants who are teachers and teacher educators in Florida via email.

\section{Results}

\section{Teacher's Identity, White Culture and White Fragility}

Teaching is a subjective endeavor. Teachers' experiences, perceptions, and positionality, particularly their racial/ethnic identity, shape their teaching practices and their interactions with their students (Nieto, 2013). Similarly, the habitus of the teachers affects their relationships with the students (Kayaalp, 2019).

Habitus differs according to class, gender, and cultural differences between people living in different geographic locations. As Bourdieu (1989, p. 18) argues "the dispositions of agents, that is, the mental structures through which [agents] apprehend the social world, their habitus are essentially the product of the internalization of the structures of that world." Therefore, the gap between a white teacher's habitus and that of an ethno-racial minority student is substantial (Kayaalp, 2014). Since habitus depends on social structures, it is unlikely to initiate change; if teachers are conditioned by unchanging and, say, racist social structures, teachers will remain racist. As DiAngelo (2011, p. 149) argues, "I do not feel guilty about racism. I didn't choose this socialization and it could not be avoided."

If the structures and norms of a culture produce and restrict a teacher's habitus, how do they affect educational justice? Culture, power, and educational justice are deeply related (Bettie, 2003). Cultural norms and power imbalances affect not only people's identity and their social location, but also their access to social institutions, including educational institutions. Students who have privileged (dominant and valued) identities because of their group membership (e.g. whiteness) have access to educational institutions and benefits not available to students with marginalized identities (e.g. a physical disability).

Not surprisingly, my participants recognized that "culture" in the United States generally means white culture. This understanding of culture excludes or misrepresents subjugated identities and cultures while over-representing people and norms from the dominant (white) culture. So, while Shakespeare remains one of the key figures of western civilization and literature, students typically have no familiarity with, say, Indigenous writers or even Indigenous people and their culture in general (Wade, 2014). Amy, a teacher educator, identifies how power and privilege play a role in American culture:

the last part of that [the aspects of culture] would be knowledge about the culture connected to issues of power and privilege in society. So that while you might understand the culture of your students and yourself, how do we connect to that? Like cultural capital? [...] If you align with certain values and beliefs of the dominant group, then that gives you more power in certain situations. 
Amy's report indicates how categories of identification (e.g., race) and the dominant values and beliefs (e.g., whiteness) help establish power imbalances in society and educational settings. Consequently, personal identities are valued or devalued according to a person's group membership (Sensoy and DiAngelo, 2017).

My participants' interviews also confirm that white fragility (DiAngelo, 2011) obstructs educational justice by maintaining racial hierarchy and protecting white people's position in that hierarchy. Sam, who is a teacher educator, touches on white fragility when discussing the emotional reactions of his white PhD students when visiting a black community in Springfield. Sam reports,

When I was working with doctorate students, we were going to be out exploring the community. One of the students said, 'I'm angry at you because you're making us come here, and this place is unsafe. You're putting my safety at risk.' Another student had her husband driving around the block, because they were so afraid that she was in danger. This is Springfield, you know. Those are doctoral students.

The defense of white fragility, as expressed by Sam's students, protects power imbalances and white privilege in society and educational settings.

While whiteness is a group membership and a social construct, white culture has its own beliefs, values, and cultural practices (e.g., gestures and taste; see Bourdieu, 1984). Sam's interview further indicates that white students' emotional responses to structural problems (such as de facto segregation) encourages them to leave an "unsafe" setting (in this case, the black neighborhood). DiAngelo (2011, p. 61) anticipates this emotional response:

Whites have not had to build tolerance for racial discomfort and thus when ra-cial discomfort arises, whites typically respond as if something is "wrong," and blame the person or event that triggered the discomfort (usually a person of color). This blame results in a socially-sanctioned array of counter-moves against the perceived source of the discomfort, including: penalization; retaliation; isolation; ostracization; and refusal to continue engagement.

Exploring the impacts of power and the dominant cultural norms on the marginalization of racial/ethnic minority youth should be the premise of educational justice. Students' identity formation and their educational experiences are determined by the dominant norms of the society (e.g., white fragility).

Sam also comments on the interplay between educational justice and the hidden racism of "colorblindness." Sam asserts,

I think being culturally responsive to me is reframing our lens and how we look at students, and communities, and families. We start seeing their strengths, and assets rather than their deficiencies. [..]When you hear a teacher says, "I don't see color." "I don't see race. They're all my babies," that trashes equity. It's not acknowledging the cultural realities of racial and cultural life.

Sam's criticism of colorblindness parallels the premises of anti-racist education. According to this approach, racism exists but colorblind teaching ignores the existence of race and thus racism. By ignoring racism, colorblind teaching itself becomes racist. As Kendi $(2019$, p. 10) argues "the language of color blindness is a mask to hide racism." Teachers' racism has a direct negative impact on students' academic achievement.

Colorblind education also ignores the identities and experiences of racial/ethnic minority students. The statement that "we are all humans, we have similar experiences" supports a white supremacist ideology which disregards social injustices and presumes that every student starts the "education race" from the same start line. Failure then becomes an individual choice, regardless of the inequities that might distinguish one student from another. Disregarding educational injustices (e.g., race and class bias) leads to deficit practices which in turn perpetuate oppressions of marginalized students (Valencia, 2012).

My study participants seemed aware of the issues of white privilege and white fragility, and how they affect educational justice. But if educational justice praxis is not just to interpret the world of education but to change it, can we find pedagogical strategies to prepare culturally aware and competent teachers for cross-cultural classrooms? My respondents had some suggestions.

\section{Culturally appropriate pedagogical models}

My data show that creating a place where pre-service teachers can engage in honest and open conversations about educational justice (including stereotypes, biases, inequalities), and make themselves vulnerable encourages educational 
justice praxis. Critical thinking, self-reflection, and multicultural literacy also help develop culturally competent pedagogical strategies.

Alyssa, a public-school teacher, discusses the positive effects of multicultural literacy in educational praxis and in acquiring culturally responsive techniques:

In my personal experience, having exposure to multicultural literature in college was such a gift. During my first year, I had a class of 19 students-18 were African-American. I might have been reading Goldilocks, and the Three Bears, and Rapunzel, and American Girl Doll. Who knows? If I didn't have that experience, I could have never realized that these students were not going to relate to these books. I can read Goldilocks but there's a book called Leola and the Honeybears that's an African-American retelling of the story. It's the same story, but there's different cultural differences in the story by using different words. Teachers may not think that it's necessary, but it's essential to pick books that your students can relate to. The great part of it is if teachers are reading these stories to their kids, they're starting, without realizing it, to understand cultural differences.

Sophie, another passionate school teacher, echoes Alyssa:

In my fifth-grade class last year, a lot of my students were Spanish-speaking students. We had to read a novel in the curriculum about immigration. Many of my students then were going through that process. Their parents are in other countries, or their parents are here, and they're scared of going back to Mexico or wherever. So, we read this novel about this girl who's from Mexico and had to move to California, back during the Depression. They felt like they could relate to the story because some of their parents are still in the process of moving. They have gone through that immigration process. They have family who are still there, and it engages these students. They were wanting to know what's going to happen next. They were willing to read, and willing to explore, and comprehend the story.

Alyssa and Sophie's comments show that the curriculum, including the lesson plan and textbooks, should relate to the students' cultural background, their identities, and their interests. Kayaalp $(2014$, p. 20) suggests that "culturally offensive teaching leads to devaluation of minority youths' native languages, confused cultural identities and lowered school performance." Therefore, culturally responsive pedagogical strategies should acknowledge and respond to existing cultural differences (such as life styles) and group history. Teaching methods should also include behaviors and attitudes that illustrate cultural awareness and cross-cultural communication (Bennett, 2006), and raise issues of equality and equity.

My findings also demonstrate that dismantling dominant cultural practices (e.g., personal space) and values (e.g., nationalism) of pre-service teachers remains challenging. Alyssa discusses the difficulty of changing the habitus of preservice teachers:

People [interns] are coming with a lot of baggage and a lot of values at their parents instilled that maybe contradicting to the things that we talk about. What to do for these students? I don't know. It's not an easy question. [...] I also think how to appeal to the more patriotic person. The person that may be very, you know, the USA all the way, and against different cultures.

Alyssa indicates that eliminating nationalism and its associated racism in classrooms can be difficult since the pre-service teachers' habitus arises from the structures of their society and culture.

In response, October, a public-school teacher, suggests that pre-service teachers need more help to understand the meaning of cultural competency and educational justice praxis. October asserts,

They have to go into classrooms with the mindset that they're specifically looking for cultural competence. I don't believe that majority of the educators know what we mean when we tell them that we want them to be culturally relevant, culturally aware, or culturally competent. I think they know what the word cultural means. I think they know what the word competent means. I don't think that they know what that means in practice.

Similarly, Nancy, a teacher educator, suggests that experience can be very educational:

When does that light bulb go off for an intern? I think it happens with exposure. We can teach him all day long in a classroom and they could hear it and maybe even understand it, but they can't apply it until they're out there. [...] I taught high school English. One of my students would sleep through my class all the time. One day I woke him up and asked him, "What is 
it?" Well, he had a baby. He was working two jobs after school and he would get home at two or three o'clock in the morning because he was washing dishes at a restaurant. That was a wake-up call for me.

October and Nancy's statements affirm that learning the conceptual framework of cultural competence is important for preservice teachers, but applying this knowledge in classrooms can be challenging. Pre-service teacher education can provide assignments to help aspiring teachers build relationships with students because cultural competency entails bonding with students, understanding their conditions, knowing their home culture and lifestyle, and accommodating their needs and expectations. Meeting students' parents or guardians and walking their neighborhood streets can lead to cultural awareness and self-awakening. October reports,

If I walked my students' home, I can tell you right now my students go right here. They go through this dirt road and it is so scary. I know why they smell like pee because I saw where they live. I saw that their house doesn't have a door knob. when you see the environment, it gives them [pre-service teachers] what we want them to have. When I look at interns, particularly the white ones, there's that something missing. It's not that they don't like the kids. It's that they're missing the understanding of where they [their students] come from. They've never seen the real hood. Once you get that like breakthrough, you never leave Title One. You know why you're here. But a lot of them, I don't think they know their purpose.

Based on my participants' statements, educational justice praxis has numerous components: a) teaching a relevant theoretical framework regarding cultural norms, identity, whiteness, and cultural competency; b) teaching social and structural problems of the society such as poverty, segregation, and structural racism; c) exercising culturally appropriate pedagogical practices such as bonding with students and meeting their parents.

\section{Conclusion}

In this study I investigated the educational justice praxis to alleviate the structural inequities faced by ethnic/racial minority students. My findings indicate that i) dominant cultural norms (whiteness) and teachers' habitus (white fragility); and ii) structural issues (racism, segregation) lead to the marginalization of students.

According to my analysis, educational justice praxis requires a close investigation of culture and cultural norms to understand the forms of domination and marginalization that affect students in educational settings. While whiteness exalts teachers' positions in society, it marginalizes non-white students' identities and their cultures; mainstream education values white and middle-class norms (Bourdieu \& Passeron, 1990). This, in turn, leads to a culture gap or clash between white teachers and non-white students because each develops a different habitus as the outcome of the unfair structures of their society.

As a response to these concerns, my study recommends that educational justice praxis should emphasize theoretical knowledge about educational equity and practical skills to implement it. Teacher education programs should help aspiring teachers learn about structural problems in society such as poverty, racism, and others, and their relation to educational inequities. Additionally, teachers and educators more generally can and should learn from their students, parents or guardians, and community, respecting their students' cultural identities and experiences.

\section{References}

[1] Anthias, F. \& Yuval-Davis, N. (1992). Racialized boundaries: Race, nation, gender, colour and class and the anti-racist struggle. London: Routledge.

[2] Bennett, M. (2006). Intercultural competence. In K. Cushner, S, Safford (Eds.), Human diversity in education. Boston: McGraw Hill Higher Education.

[3] Bettie, J. (2003). Women without class: girls, race and identity. Berkeley: University of California Press.

[4] Bourdieu, P. (1984). Distinction: A social critique of the judgment of taste. Cambridge: Harvard University Press. Bourdieu, P. (1989). Social space and symbolic power. Sociological Theory, 7, 14-25.

[5] Bourdieu, P. \& Passeron, J. (1990). Reproduction in education, society and culture. London: Sage Publications.

[6] Cohen, P. (1999), New ethnicities, old racisms. London: Zed Books.

[7] DiAngelo, R. (2011). White Fragility. International Journal of Critical Pedagogy, Vol 3 (3) (2011) pp 54-70.

[8] DiAngelo, R. (2018). White Fragility: Why It is so hard for white people to talk about racism. Boston: Beacon Press. 
[9] Gorski, P. (2016). Rethinking the Role of "Culture" in Educational Equity: From Cultural Competence to Equity Literacy. Multicultural Perspectives. 18 (4), 221-26.

[10] Gay, G. (2010). Culturally Resonsive Teaching. New York, Teachers College.

[11] Gramsci, Antonio (1971). Selections from the Prison Notebooks. New York: International Publishers.

[12] Hall, S. (2000). Old and new identities, old and new ethnicities. In Les Back and John Solomos (Eds.), Theories of race and racism (pp.144-154). London: Routledge.

[13] Kayaalp, D. (2014). Educational inclusion/exclusion of Turkish immigrant youth in Vancouver, Canada: A critical analysis. International Journal of Inclusive Education, 18(7), 655-668.

[14] Kayaalp, D. (2019). Towards culturally responsive education: A qualitative approach. European Journal of Education, 2(2), 1-9.

[15] Kendi, I. (2019). How to be an anti-racist. New York: Random House Books

[16] Lewis, G . (2000). Stuart Hall and social policy: An encounter of strangers. In P. Gilroy, L. Grossberg, \& A. McRobbie (Eds.), Without guarantees: In honour of Stuart Hall (pp. 193-201). London: Verso.

[17] Nieto, S. (2013). Finding Joy in Teaching Students of Diverse Backgrounds (eBook). SBN 978-0-325-05680-7 I 0-325-05680-3 / SKU EBK05680.

[18] Sensoy, O. \& DiAngelo, R. (2017). Is everyone really equal? New York: Teachers College.

[19] Wade, L. 2014. U.S. Schools Teach Children That Native Americans Are History. Sociological Images. https://thesocietypages.org/socimages/2014/11/24/u-s-schools-teach-children-that-native-americans-arehistoryl

[20] Valencia, R. (2012). Deficit Thinking Paradigm. (Ed.) James Banks in Encyclopedia of Diversity in Education. Sage Publications. 